\title{
Mechanism of $\mathrm{CaF}_{2}$ under Vacuum Carbothermal Conditions for Recovering Nickel, Iron, and Magnesium from Garnierite
}

\author{
Qiang Wang ${ }^{1,2,3,4}$, Xupeng Gu ${ }^{1,2,3,4}$, Tao Qu ${ }^{1,2,3,4, *}$, Lei Shi ${ }^{1,2,3,4}$, Mingyang Luo ${ }^{1,2,3,4}$, \\ Bin Yang 1,2,3,4 and Yongnian Dai 1,2,3,4
}

1 State Key Laboratory of Complex Non-ferrous Metal Resources Clear Utilization, Kunming University of Science and Technology, Kunming 650093, China; wqiang_doc@163.com (Q.W.); xvpenggu@163.com (X.G.); ahdyshilei@163.com (L.S.); 18712711093@163.com (M.L.); kgyb2005@126.com (B.Y.); daiyn@cae.cn (Y.D.)

2 National Engineering Laboratory for Vacuum Metallurgy, Kunming University of Science and Technology, Kunming 650093, China

3 Key Laboratory of Vacuum Metallurgy for Nonferrous Metal of Yunnan Province, Kunming University of Science and Technology, Kunming 650093, China

4 Faculty of Metallurgical and Energy Engineering, Kunming University of Science and Technology, Kunming 650093, China

* Correspondence: qutao_82@126.com

Received: 15 November 2019; Accepted: 9 January 2020; Published: 15 January 2020 updates

\begin{abstract}
Nickel laterite ore is divided into three layers and the garnierite examined in this study belongs to the third layer. Garnierite is characterized by high magnesium and silicon contents. The main contents of garnierite are silicates, and nickel, iron, and magnesium exist in silicates in the form of lattice exchange. Silicate minerals are difficult to destroy so are suitable for smelting using high-temperature pyrometallurgy. To solve the problem of the large amounts of slag produced and the inability to recycle the magnesium in the traditional pyrometallurgical process, we propose a vacuum carbothermal reduction and magnetic separation process to recover nickel, iron, and magnesium from garnierite, and the behavior of the additive $\mathrm{CaF}_{2}$ in the reduction process was investigated. Experiments were conducted under pressures ranging from 10 to $50 \mathrm{~Pa}$ with different proportions of $\mathrm{CaF}_{2}$ at different temperatures. The experimental data were obtained by various methods, such as thermogravimetry, differential scanning calorimetry, scanning electron microscopy, energy dispersive spectrometry, X-ray diffraction, and inductively coupled plasma atomic emission spectroscopy. The analysis results indicate that $\mathrm{CaF}_{2}$ directly reacted with $\mathrm{Mg}_{2} \mathrm{SiO}_{4}, \mathrm{MgSiO}_{3}, \mathrm{Ni}_{2} \mathrm{SiO}_{4}$, and $\mathrm{Fe}_{2} \mathrm{SiO}_{4}$, which were isolated from the bearing minerals, to produce low-melting-point compounds $\left(\mathrm{FeF}_{2}\right.$, $\mathrm{MgF}_{2}, \mathrm{NiF}_{2}$, etc.) at 1315 and $1400 \mathrm{~K}$. This promoted the conversion of the raw materials from a solid-solid reaction to a liquid-liquid reaction, accelerating the mass transfer and the heat transfer of Fe-Ni particles, and formed Si-Ni-Fe alloy particles with diameters of approximately of $20 \mathrm{~mm}$. The smelting materials appeared stratified, hindering the reduction of magnesium. The results of the experiments indicate that at $1723 \mathrm{~K}$, the molar ratio of ore/C was $1: 1.2$, the addition of $\mathrm{CaF}_{2}$ was $3 \%$, the recovery of $\mathrm{Fe}$ and $\mathrm{Ni}$ reached $82.97 \%$ and $98.21 \%$ in the vacuum carbothermal reduction-magnetic separation process, respectively, and the enrichment ratios of Fe and Ni were maximized, reaching 3.18 and 9.35 , respectively.
\end{abstract}

Keywords: garnierite; vacuum carbothermal reduction; mechanism; $\mathrm{CaF}_{2}$; recovery 


\section{Introduction}

Nickel is an important metal in the modern world, used in stainless steel, electroplating, rechargeable batteries, and super alloys [1,2] to improve peoples' quality of life, and widely used in improving human health in nickel-containing medical devices, medical artificial bones, stents, and new anticancer drugs [3-6]. With the increase of demand for nickel and the rapid depletion of nickel sulfide ore, more attention is being paid to low-grade nickel laterite ore [7-9]. Generally, nickel laterite ore can be divided into three categories: limonitic ore, transition ore, and garnierite [10-12]. According to the different compositions of every layer, nickel laterite ores are treated using different methods, including pyrometallurgical and hydrometallurgical methods [13]. Hydrometallurgical techniques are more applicable to limonitic ore, which includes ammonia-ammonium carbonate leaching, pressure acid leaching (PAL), and high-pressure acid leaching (HPAL) [14-20]. Garnierite is more suitable for pyrometallurgical methods due to the high content of magnesium. At present, the mature industrial pyrometallurgical methods include rotary kilns-electric furnaces (RKEF) and Krupp-Ren [21-23].

Previous studies reported that $\mathrm{CaF}_{2}$ is used as additive in pyrometallurgy of nickel laterite ore. $\mathrm{Ma}$ et al. [24] studied the influence of $\mathrm{CaF}_{2}$ in the nickel laterite ore reduction process. The results indicated that the aggregation of nickel and iron particles increased significantly from 1 to $200 \mu \mathrm{m}$ after adding $\mathrm{CaF}_{2}$, which indicates that $\mathrm{CaF}_{2}$ can effectively reduce the surface tension of the newly formed alloy. This is beneficial for magnetic separation process and increases the nickel grade. Cao et al. [25] determined the production and enrichment rates of nickel and iron under different smelting conditions by changing the amount of added reducing agent and comparing the different production rates of ferronickel with $\mathrm{CaF}_{2}, \mathrm{CaF}_{2}$, and hydrated lime. However, the authors did not report the optimal conditions, nor did they specifically explore the mechanism of $\mathrm{CaF}_{2}$ and hydrated lime in the reduction process.

Previous studies only focused on the extraction of $\mathrm{Ni}$ and $\mathrm{Fe}$, and ignored the extraction of higher values magnesium. The behavior of $\mathrm{CaF}_{2}$ in the reduction process has not been reported in the literature. Therefore, we propose a vacuum carbothermal reduction-magnetic separation process to recover nickel, iron, and magnesium from garnierite, and investigated the behavior of the added $\mathrm{CaF}_{2}$ in the reduction process. In this process, magnesium was reduced to magnesium vapor and condensed to obtain magnesium metal $[26,27]$. The experimental flow chart is shown in Figure 1.

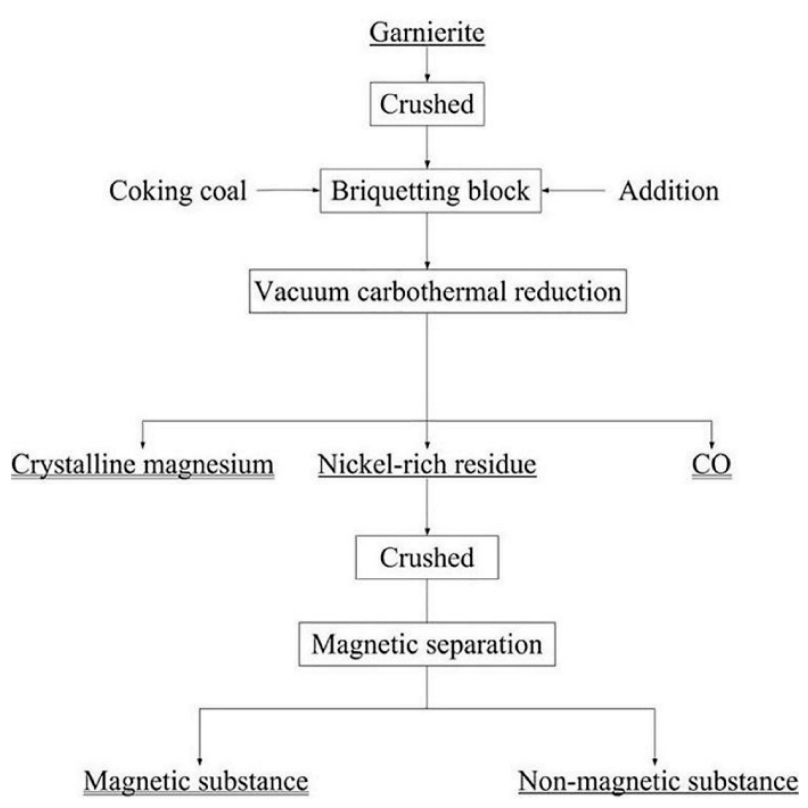

Figure 1. Work flow of the experimental procedure. 


\section{Materials and Methods}

\subsection{Raw Materials}

The garnierite sample used in this study was obtained from Yuanjiang, Yunnan province, China. The X-ray diffraction (XRD) analysis and the chemical analysis of the sample are shown in Figure 2 and Table 1. According to the XRD analysis, we found that the major phases of garnierite are lizardite, nepouite, kaolinite, and quartz. $\mathrm{CaF}_{2}$ was used as an additive in this study. The compositions of $\mathrm{CaF}_{2}$ and the coking coal are listed in Tables 2 and 3, respectively.

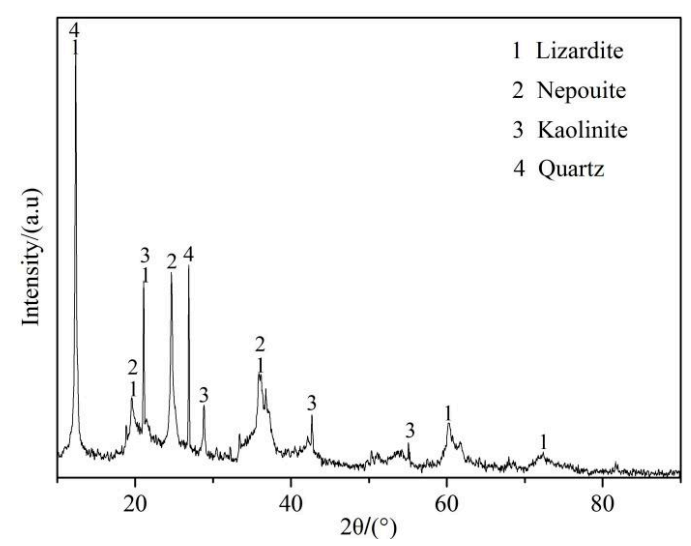

Figure 2. X-ray diffraction (XRD) patterns of garnierite.

Table 1. The composition of the garnierite (wt. \%).

\begin{tabular}{cccccccc}
\hline Component & $\mathrm{SiO}_{2}$ & $\mathrm{MgO}$ & $\mathrm{Fe}$ & $\mathrm{Ni}$ & $\mathrm{Co}$ & $\mathrm{Al}_{2} \mathrm{O}_{3}$ & Others \\
\hline Content & 38.82 & 22.83 & 12.66 & 0.72 & 0.03 & 4.57 & 20.37 \\
\hline
\end{tabular}

Table 2. The composition of the $\mathrm{CaF}_{2}$ (wt. \%).

\begin{tabular}{cccccccc}
\hline Component & $\mathrm{CaF}_{2}$ & $\mathrm{Si}$ & $\mathrm{Fe}$ & Heavy Metal & Chloride & Sulfate & Nitride \\
\hline Content & $\geq 98.5$ & $\leq 0.01$ & $\leq 0.003$ & $\leq 0.003$ & $\leq 0.01$ & $\leq 0.05$ & $\leq 0.005$ \\
\hline
\end{tabular}

Table 3. The composition of the coking coal (wt \%).

\begin{tabular}{cccccc}
\hline Component & C & Ash & Moisture & Volatile & K (g) \\
\hline Content & 85.83 & 12.02 & 0.14 & 2.01 & 7187.2 \\
\hline
\end{tabular}

\subsection{Experimental Method and Equipment}

All garnierite and coking coal were crushed and screened to less than $74 \mu \mathrm{m}$, and the ore and $\mathrm{C}$ were mixed in a molar ratio of $1: 1.2$. The masses of $\mathrm{CaF}_{2}$, which were $0 \%, 3 \%, 6 \%, 9 \%$, and $12 \%$, were studied with regard to their behavior and effect on the experimental results. In the first, the mixed materials were formed into pellets of $\Phi 20 \mathrm{~mm} \times 20 \mathrm{~mm}$ at $5 \mathrm{MPa}$ and then placed in a corundum crucible. Heating was applied under pressures ranging from 10 to $50 \mathrm{~Pa}$ by placing the corundum crucible into a graphite crucible in a vacuum furnace. The system temperature was raised from room temperature to the desired temperature and was held this temperature for $120 \mathrm{~min}$. After, the reaction product was cooled to room temperature and removed. The schematic model of the vacuum distillation furnace for experiment is shown in Figure 3. For the nickel-rich residue, we used a vibrating grinding machine to crush the material to approximately $74 \mu \mathrm{m}$, and we placed the crushed materials into a planetary ball mill for $4 \mathrm{~h}$ of ball milling, allowing the materials to be mixed thoroughly and uniformly. After the ball milling was completed, the materials were removed, sampled, and sent for analyses, and magnetic separation was conducted for the remaining residue. 


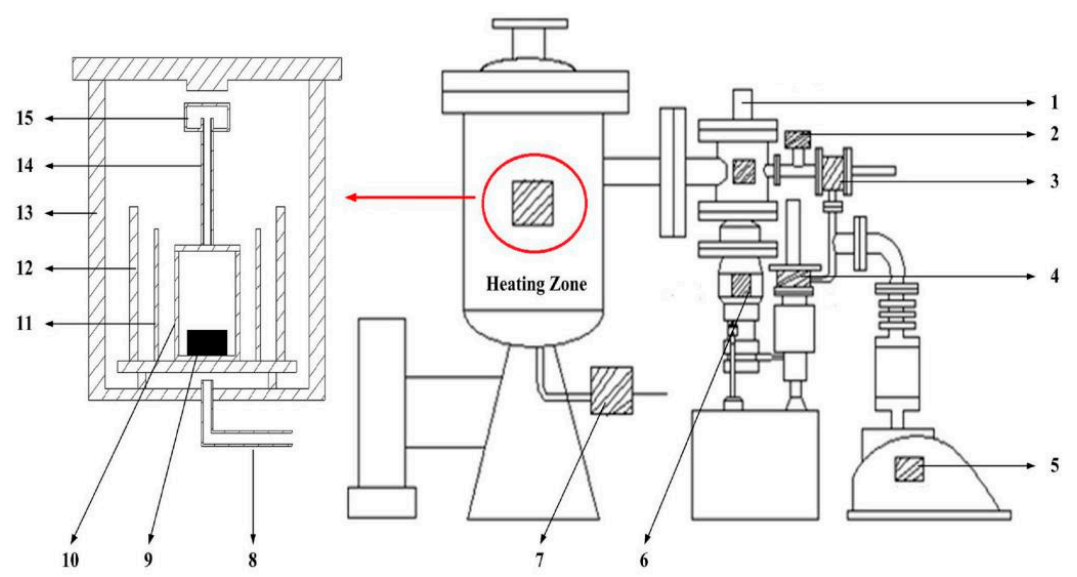

Figure 3. Schematic model of the vacuum distillation furnace: 1 , high vacuum valve; 2 , release valve; 3 , bypass valve; 4 , main valve; 5 , rotary vane pump; 6 , diffusion pump; 7 , inflation valve; 8 , vacuum pipe; 9 , raw materials; 10 , graphite crucible; 11 , graphite heater; 12 , heat shield; 13 , water cooled walls; 14 , graphite condensing pipe; and 15, condensation.

The remaining nickel-rich residue was ground and screened to $45 \mu \mathrm{m}$, and then wet magnetic separation was conducted. The N52 trademark of neodymium iron, with a surface magnetic field strength approximately 1.44-1.48 $\mathrm{T}$, was used to adsorb the magnetic material. A magnetic substance was obtained after three magnetic separations.

The recovery $\alpha_{1}$ of the reduction process is expressed as:

$$
\alpha_{1}=\mathrm{M}_{\mathrm{a}} / \mathrm{M}_{0}
$$

where $\mathrm{M}_{\mathrm{a}}$ and $\mathrm{M}_{0}$ refer to the masses of metals in the nickel-rich residue and in the ore, respectively. The recovery $\alpha_{2}$ of the reduction magnetic separation process is expressed as:

$$
\alpha_{2}=M_{b} / M_{a}
$$

where $\mathrm{M}_{\mathrm{a}}$ and $\mathrm{M}_{\mathrm{b}}$ refer to the masses of metals in the magnetic substances and in the nickel-rich residue, respectively. The recovery $\alpha$ of the whole process is expressed as:

$$
\alpha=\alpha_{1} \times \alpha_{2} .
$$

\subsection{Analysis Methods}

The nickel-rich residue was identified with X-ray diffraction (XRD) Dmax-R diffractometer

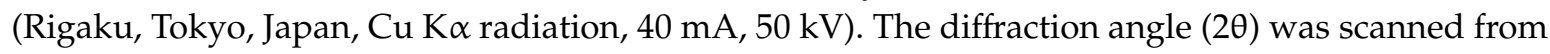
$10^{\circ}$ to $90^{\circ}$ in $4^{\circ}$ increments. The morphology and the elemental composition of the particular regions were determined using scanning electron microscopy (SEM, TM-3030 Plus, HITACHI, Tokyo, Japan) equipped with energy-dispersive X-ray spectroscopy (EDS, INCA, Oxford, UK). Chemical analysis of the nickel-rich residue was performed using inductively coupled plasma atomic emission spectroscopy (ICP-OES) with an Optima 8000 (Perkin Elmer, Waltham MA, USA).

\section{Results and Discussion}

\subsection{Experimental Phenomena and XRD/EDS Analysis}

During the removal of the Fe-Ni-rich residue, we found different phenomena at the end of the experiment; no melting occurred at the experimental temperature when the addition of $\mathrm{CaF}_{2}$ was $0 \%$. When the addition of $\mathrm{CaF}_{2}$ was $3 \%$, the raw materials appeared to experience micro-melting at 1623 and $1723 \mathrm{~K}$, however, the raw materials melted completely at $1823 \mathrm{~K}$, as shown in Figure 4. 


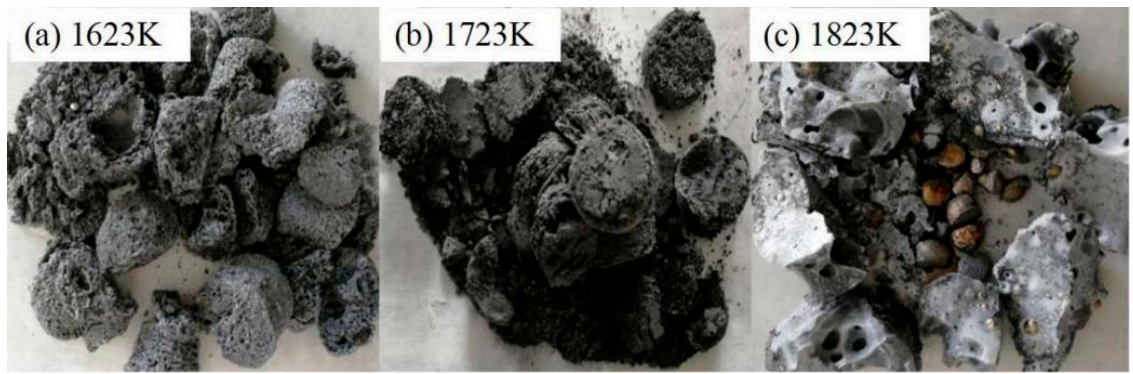

Figure 4. The reduced slag at (a) $1623 \mathrm{~K}$, (b) $1723 \mathrm{~K}$, and (c) $1823 \mathrm{~K}$ with $3 \% \mathrm{CaF}_{2}$.

The left part of Figure 5 is the picture of the material removed after the vacuum carbothermal reduction. The black fluffy material in the picture is located on the top of the corundum crucible. After pouring the black fluffy material, we found that the material in the corundum crucible completely melted, with a layer of gray white material solidified with no hole on the surface on the top of the melted material. After the corundum crucible was broken, we found many large cavities in the melted material, and the color of solidified material below was gray black. Finally, large metal particles were found at the bottom of the corundum crucible. According to the above phenomena, we drew a layering diagram of the materials in the corundum crucible, as shown in the right part of Figure 5.

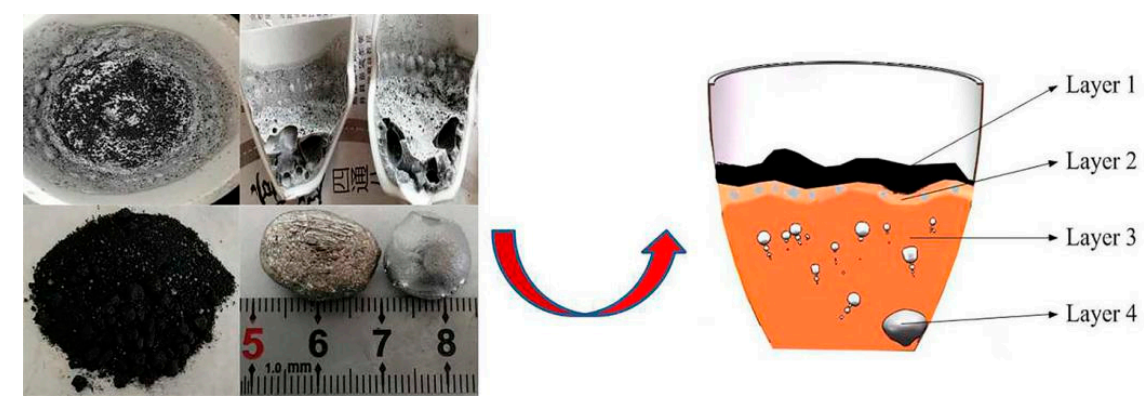

Figure 5. Phenomena of stratification for the residue after reduction at the experimental temperature with more than $3 \% \mathrm{CaF}_{2}$.

XRD and SEM/EDS analysis were conducted to determine the phase of black fluffy material and the composition of silver-white metal particles of the first layer, as shown in Figure 6. According to XRD analysis, the black fluffy material was mainly carbon, and the ferrosilicon should be the silver-white metal particles, which mixed with the black matter. SEM/EDS analysis showed that the carbon content reached $75.28 \%$, the remaining materials were mainly Fe and F, and the contents of Fe and F were $12.71 \%$ and $5.30 \%$, respectively.

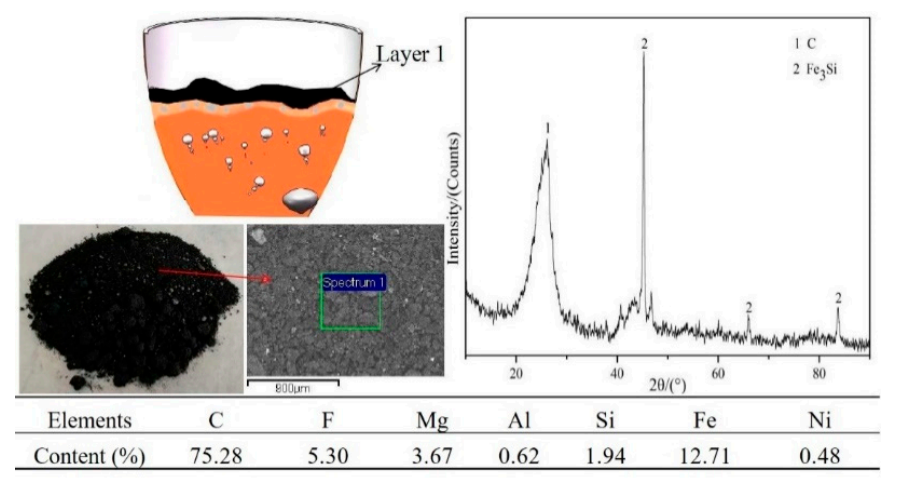

Figure 6. XRD pattern and energy-dispersive X-ray spectroscopy (EDS) analysis of Layer 1. 
The thermodynamic analysis of Equation (4) performed at $50 \mathrm{~Pa}$ showed that the initial reaction temperature of the production of $\mathrm{FeF}_{2}$ was $1398 \mathrm{~K}$, and $\mathrm{FeF}_{2}$ will directly sublimate at $1373 \mathrm{~K}$. We considered that the source of $\mathrm{F}$ was the volatilization of $\mathrm{FeF}_{2}$, with part of the Fe sourced from the ferrosilicon mixed in black matter, and the other part from the volatilization of $\mathrm{FeF}_{2}$. The equation can be expressed as:

$$
\begin{gathered}
\mathrm{Fe}_{2} \mathrm{SiO}_{4(\mathrm{~s})}+6 \mathrm{C}_{(\mathrm{s})}+\mathrm{CaF}_{2(\mathrm{~s})}=\mathrm{FeSi}_{(\mathrm{s})}+\mathrm{CaC}_{2(\mathrm{~s})}+\mathrm{FeF}_{2(\mathrm{~g})}+4 \mathrm{CO}(\mathrm{g}) \\
\Delta \mathrm{G}_{\mathrm{T}}=1731.126-1.238 \mathrm{~T} \mathrm{~kJ} / \mathrm{mol}
\end{gathered}
$$

XRD and SEM/EDS analysis were performed to determine the phase and composition of the second layer, as shown in Figure 7. The XRD results showed that the white matter phase of the second layer was $\mathrm{MgAl}_{2} \mathrm{O}_{4}$, and the SEM/EDS results indicated that the white matter mainly contained $\mathrm{Mg}$, $\mathrm{Al}$, and $\mathrm{O}$, at $14.28 \%, 26.58 \%$, and $50.38 \%$, respectively.

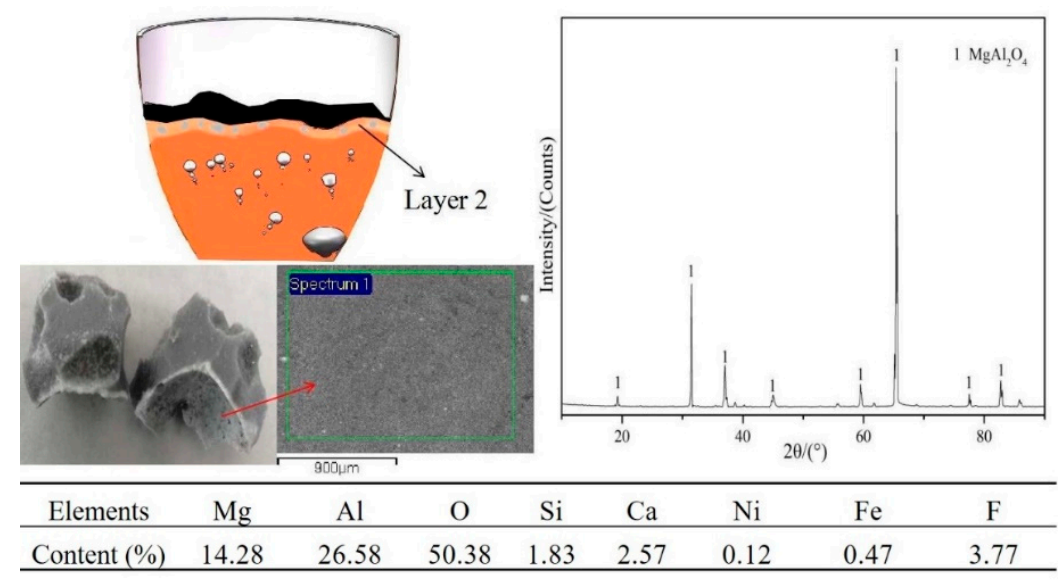

Figure 7. XRD pattern and EDS analysis of Layer 2.

Combined with the thermodynamic calculation, Equations (5) and (6) showed that the reaction initial temperature for the formation of $\mathrm{MgAl}_{2} \mathrm{O}_{4}$ was $875 \mathrm{~K}$, so the reaction to form $\mathrm{MgAl}_{2} \mathrm{O}_{4}$ could occur at the experimental conditions. The reason of $\mathrm{Al}_{2} \mathrm{O}_{3}$ did not reduce by carbon was the initial temperature of the reduction reaching $1691 \mathrm{~K}$ under the pressure of $50 \mathrm{~Pa}$, which is much larger than the reaction initial temperature of $\mathrm{MgAl}_{2} \mathrm{O}_{4}$. The $\mathrm{MgAl}_{2} \mathrm{O}_{4}$ is denser than carbon, so the carbon floats above the $\mathrm{MgAl}_{2} \mathrm{O}_{4}$. The equations can be expressed as:

$$
\begin{gathered}
\mathrm{Mg}_{2} \mathrm{SiO}_{4(\mathrm{~s})}+2 \mathrm{Al}_{2} \mathrm{O}_{3(\mathrm{~s})}=2 \mathrm{MgAl}_{2} \mathrm{O}_{4(\mathrm{~s})}+\mathrm{SiO}_{2(\mathrm{~s})} \\
\Delta \mathrm{G}_{\mathrm{T}}=19.255-0.022 \mathrm{~T} \mathrm{~kJ} / \mathrm{mol} \\
\mathrm{Al}_{2} \mathrm{O}_{3(\mathrm{~s})}+3 \mathrm{C}_{(\mathrm{s})}=2 \mathrm{Al}(\mathrm{s})+3 \mathrm{CO}(\mathrm{g}) \\
\Delta \mathrm{G}_{\mathrm{T}}=1344.640-0.795 \mathrm{~T} \mathrm{~kJ} / \mathrm{mol} .
\end{gathered}
$$

XRD and SEM/EDS analysis were performed to determine the phase and composition of the material in the third layer as well, as shown in Figure 8. XRD analysis revealed that the main phases in the third layer were $\mathrm{Mg}_{2} \mathrm{SiO}_{4}$ and $\mathrm{MgAl}_{2} \mathrm{O}_{4} ; \mathrm{SEM} / \mathrm{EDS}$ analysis showed that the main elements of this layer were $\mathrm{Mg}$ and $\mathrm{Si}$, with contents of $45.97 \%$ and $29.10 \%$, respectively, mixed with a small amount of $\mathrm{F}, \mathrm{Fe}, \mathrm{Ca}$, and $\mathrm{Al}$. According to the thermodynamic calculation in Equation (7), the reaction initial temperature of $\mathrm{Mg}_{2} \mathrm{SiO}_{4}$ under the pressure of $50 \mathrm{~Pa}$ was $1472 \mathrm{~K}$, which is higher than the melt initial temperature. According to the analysis of the first and second layers, we found that after the melting, 
the carbon and the materials stratified, so most of the magnesium was not reduced. The equation can be expressed as:

$$
\begin{gathered}
3 \mathrm{Mg}_{2} \mathrm{SiO}_{4(\mathrm{~s})}+6 \mathrm{C}_{(\mathrm{s})}+2 \mathrm{CaF}_{2(\mathrm{~s})}=6 \mathrm{Mg}(\mathrm{g})+6 \mathrm{CO}_{(\mathrm{g})}+2 \mathrm{CaSiO}_{3(\mathrm{~s})}+\mathrm{SiF}_{4(\mathrm{~g})} \\
\Delta \mathrm{G}_{\mathrm{T}}=4297.884-2.920 \mathrm{~T} \mathrm{~kJ} / \mathrm{mol} .
\end{gathered}
$$

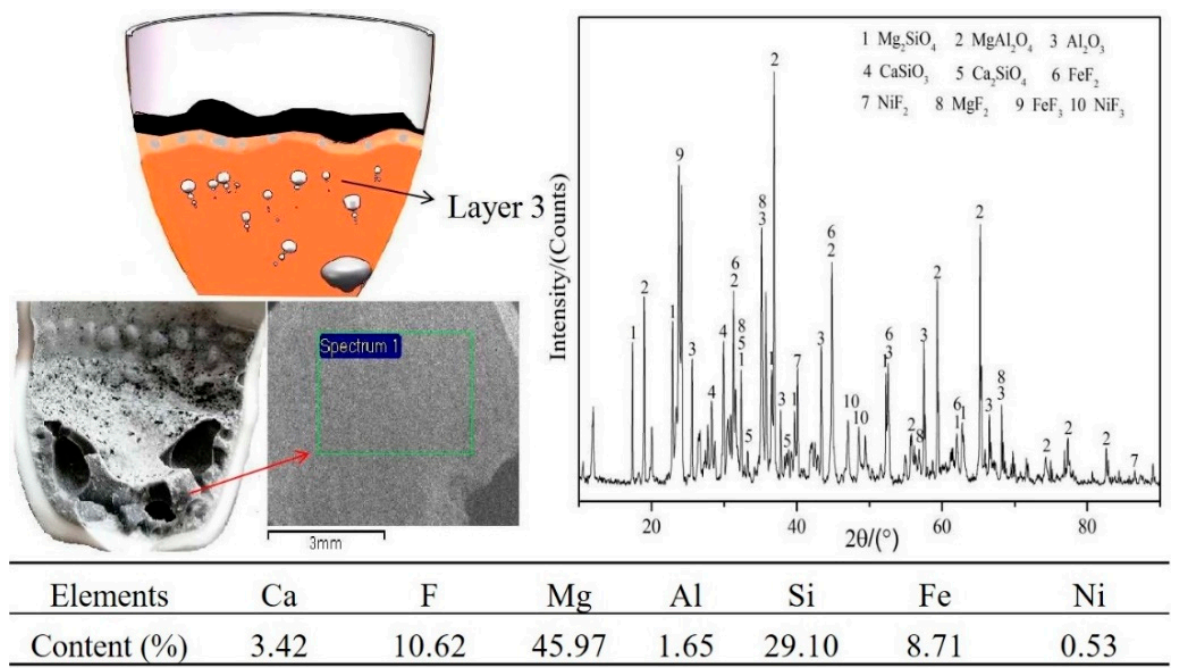

Figure 8. XRD pattern and EDS analysis of Layer 3.

According to the experimental findings, due to the block created by second layer, many bubbles were trapped underneath, so the $\mathrm{Mg}$ vapor could not overflow. This further hindered the reduction, so a large amount of $\mathrm{Mg}_{2} \mathrm{SiO}_{4}$ remained in the materials, and a large amount of $\mathrm{Mg}_{2} \mathrm{SiO}_{4}$ formed after the end of the experiment. The density of $\mathrm{Mg}_{2} \mathrm{SiO}_{4}$ is greater than that of $\mathrm{MgAl}_{2} \mathrm{O}_{4}$, resulting in $\mathrm{MgAl}_{2} \mathrm{O}_{4}$ floating above the $\mathrm{Mg}_{2} \mathrm{SiO}_{4}$.

$\mathrm{XRD}$ and SEM/EDS analysis were performed to determine the phase and composition of the fourth layer, as shown in Figure 9. XRD analysis revealed that the fourth layer was mainly $\mathrm{Fe}_{X} \mathrm{Si}_{Y}$ in various compositions. SEM/EDS analysis revealed that the layer mainly elements were $\mathrm{Fe}, \mathrm{Ni}$, and $\mathrm{Si}$, with contents of $66.90 \%, 4.15 \%$, and $25.72 \%$, respectively.

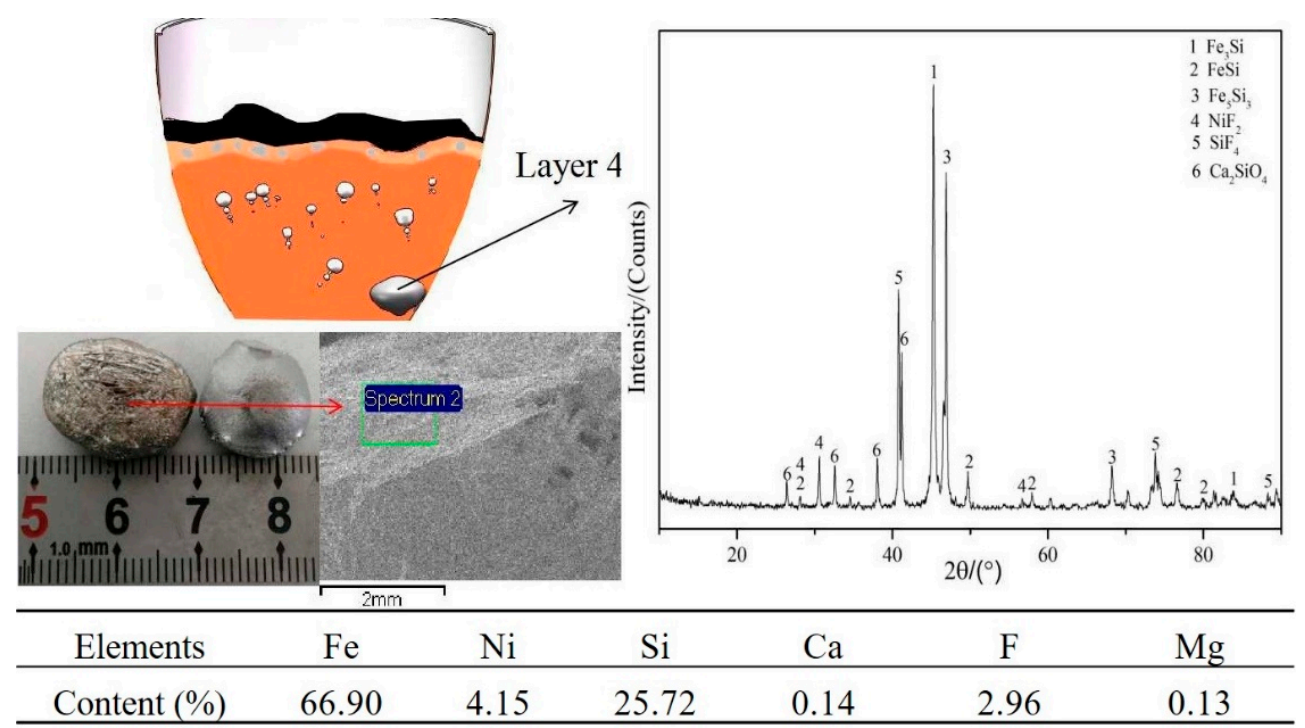

Figure 9. XRD pattern and EDS analysis of Layer 4. 
From the thermodynamic calculations of Equations (4) and (8)-(10), we found that the formation of $\mathrm{Fe}, \mathrm{Fe}_{X} \mathrm{Si}_{Y}, \mathrm{Ni}$, and FeNi formed before the materials melted. Under the pressure of $50 \mathrm{~Pa}$, the initial temperature of reactions were $1344,808,618$, and $1389 \mathrm{~K}$, respectively. After the materials melted, the mass transfer and heat transfer of $\mathrm{Ni}$ and Fe accelerated, forming a large particle of $\mathrm{Fe}-\mathrm{Ni}-\mathrm{Si}$ ternary alloy. Due to being denser than $\mathrm{Mg}_{2} \mathrm{SiO}_{4}$, it sunk into the bottom of the crucible to form the fourth layer. The equations can be expressed as:

$$
\begin{gathered}
3 \mathrm{Fe}_{2} \mathrm{SiO}_{4(\mathrm{~s})}+6 \mathrm{C}_{(\mathrm{s})}+2 \mathrm{CaF}_{2(\mathrm{~s})}=6 \mathrm{Fe}_{(\mathrm{s})}+6 \mathrm{CO}(\mathrm{g}) \\
\Delta \mathrm{G}_{\mathrm{T}}=1336.421-1.653 \mathrm{~T} \mathrm{~kJ} / \mathrm{mol} \\
3 \mathrm{Ni}_{2} \mathrm{SiO}_{4(\mathrm{~s})}+6 \mathrm{C}_{(\mathrm{s})}+2 \mathrm{CaF}_{2(\mathrm{~s})}=6 \mathrm{Ni}_{(\mathrm{s})}+6 \mathrm{CO}(\mathrm{g}) \\
\Delta \mathrm{G}_{\mathrm{T}}=1110.829-1.797 \mathrm{~T} \mathrm{~kJ} / \mathrm{mol} \\
\mathrm{Ni}_{2} \mathrm{SiO}_{4(\mathrm{~s})}+6 \mathrm{C}_{(\mathrm{s})}+\mathrm{CaF}_{2(\mathrm{~s})}=\mathrm{NiSi}_{(\mathrm{s})}+\mathrm{CaC}_{2(\mathrm{~s})}+\mathrm{NiF}_{2(\mathrm{~s})}+4 \mathrm{CO}_{(\mathrm{g})} \\
\Delta \mathrm{G}_{\mathrm{T}}=1384.267-1.055 \mathrm{~T} \mathrm{~kJ} / \mathrm{mol}
\end{gathered}
$$

At the end of the experiment, a dense condensate with a silvery white metallic luster was found on the lid, as shown in Figure 10. XRD and SEM/EDS analysis were performed to determine the phase and composition of the condensate. XRD analysis revealed that condensate was mainly calcium-silicon compounds. SEM/EDS analysis showed that the elemental contents of Si, Ca, and Fe were 54.85\%, $16.58 \%$, and $8.47 \%$, respectively. From the thermodynamic calculations of Equations (7)-(9) and (11)-(13), we found that the initial temperatures of the formation of $\mathrm{SiF}_{4}$ and $\mathrm{SiO}$ were 1472, 808, 618, 1085,961 , and $1431 \mathrm{~K}$ under the pressure of $50 \mathrm{~Pa}$, respectively. Therefore, the $\mathrm{Si}$ in the condensate was mainly produced from the condensation of $\mathrm{SiF}_{4}$ and $\mathrm{SiO}$, the Fe from the sublimation of $\mathrm{FeF}_{2}$, and $\mathrm{Ca}$ from the condensation of calcium compounds. The equations can be expressed as:

$$
\begin{gathered}
\mathrm{Fe}_{2} \mathrm{SiO}_{4(\mathrm{~s})}+3 \mathrm{C}_{(\mathrm{s})}=\mathrm{SiO}_{(\mathrm{g})}+2 \mathrm{Fe}_{(\mathrm{s})}+3 \mathrm{CO}_{(\mathrm{g})} \\
\Delta \mathrm{G}_{\mathrm{T}}=1044.890-0.962 \mathrm{TJ} / \mathrm{mol} \\
\mathrm{Ni}_{2} \mathrm{SiO}_{4(\mathrm{~s})}+3 \mathrm{C}_{(\mathrm{s})}=\mathrm{SiO}_{(\mathrm{g})}+2 \mathrm{Ni}_{(\mathrm{s})}+3 \mathrm{CO}_{(\mathrm{g})} \\
\Delta \mathrm{G}_{\mathrm{T}}=968.751-1.008 \mathrm{~T} \mathrm{~kJ} / \mathrm{mol} \\
\mathrm{SiO}_{2(\mathrm{~s})}+\mathrm{C}_{(\mathrm{s})}=\mathrm{SiO}_{(\mathrm{g})}+\mathrm{CO}_{(\mathrm{g})} \\
\Delta \mathrm{G}_{\mathrm{T}}=697.671-0.487 \mathrm{~T} \mathrm{~kJ} / \mathrm{mol}
\end{gathered}
$$
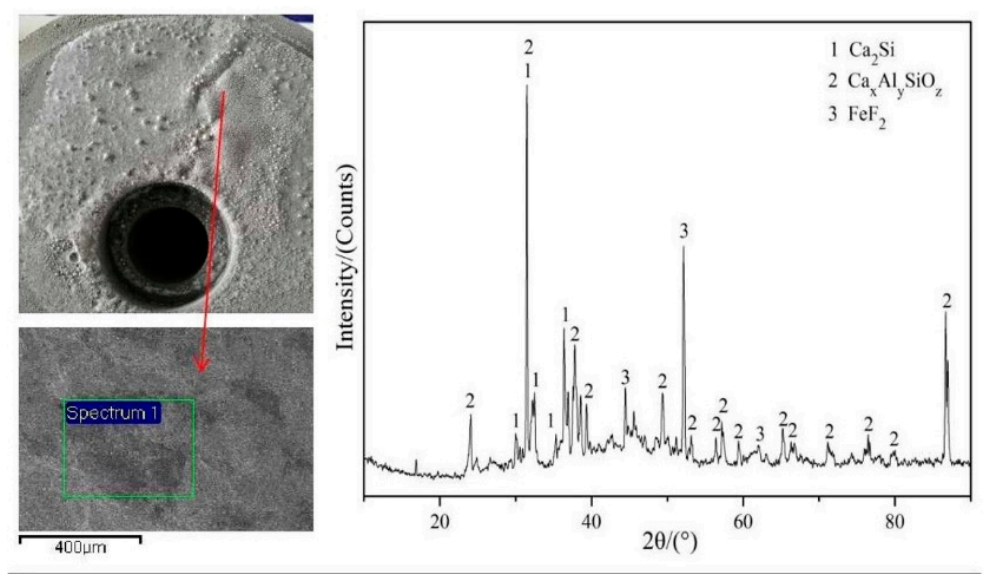

\begin{tabular}{ccccccc}
\hline Elements & $\mathrm{Si}$ & $\mathrm{Ca}$ & $\mathrm{O}$ & $\mathrm{Al}$ & $\mathrm{Fe}$ & $\mathrm{F}$ \\
\hline Content (\%) & 54.85 & 16.58 & 10.38 & 4.85 & 8.47 & 5.13 \\
\hline
\end{tabular}

Figure 10. XRD pattern and EDS analysis of the condensate on the graphite crucible lid. 
According to the above analysis of the phase and composition of each layer of materials, we found that the first layer was mainly coking coal, the small silver-white metal particles were $\mathrm{Fe}-\mathrm{Ni}-\mathrm{Si}$, and the main component of the second transition layer was $\mathrm{MgAl}_{2} \mathrm{O}_{4}$. The third layer was mainly $\mathrm{Mg}_{2} \mathrm{SiO}_{4}$ with a small amount of $\mathrm{MgAl}_{2} \mathrm{O}_{4}$ and calcium-silicon compounds, and the large metal particles in the fourth layer were Fe-Ni-Si ternary alloy. The condensate on the lid was mainly Si.

\subsection{Behavior of $\mathrm{CaF}_{2}$}

The thermogravimetry-differential scanning calorimetry (TG and DSC) curves of the garnierite are shown in Figure 11. We observed three peaks at different temperatures. According to a previous report [28], the first endothermic peak at $352 \mathrm{~K}$ represents the loss of the adsorption water, the second endothermic peak at $885.4 \mathrm{~K}$ represents the dehydroxylation of the lizardite, and the third strong exothermic peak at $1097.8 \mathrm{~K}$ represents the decomposition of $\mathrm{Mg}_{3} \mathrm{Si}_{2} \mathrm{O}_{7}$. The process is expressed in Equations (14) and (15).

$$
\begin{gathered}
\mathrm{Mg}_{3} \mathrm{Si}_{2} \mathrm{O}_{5}(\mathrm{OH})_{4(\mathrm{~s})}=\mathrm{Mg}_{3} \mathrm{Si}_{2} \mathrm{O}_{7(\mathrm{~s})}+2 \mathrm{H}_{2} \mathrm{O}_{(\mathrm{g})} \\
\mathrm{Mg}_{3} \mathrm{Si}_{2} \mathrm{O}_{7(\mathrm{~s})}=\mathrm{Mg}_{2} \mathrm{SiO}_{4(\mathrm{~s})}+\mathrm{MgSiO}_{3(\mathrm{~s})}
\end{gathered}
$$

The TG and DSC curves of the garnierite with $\mathrm{CaF}_{2}$ are shown in Figure 12. By comparing Figures 11 and 12, we found two more endothermic peaks at 1315 and $1400 \mathrm{~K}$. The two endothermic peaks represented the conversion of the raw materials from solid to liquid, which produced low-melting-point compounds such as $\mathrm{FeF}_{2}, \mathrm{NiF}_{2}$, and $\mathrm{MgF}_{2}$. The thermodynamic calculations in Equations (4), (10) and (16) were performed at $50 \mathrm{~Pa}$. The equations can be expressed as:

$$
\begin{gathered}
\mathrm{Mg}_{2} \mathrm{SiO}_{4(\mathrm{~s})}+\mathrm{SiF}_{4(\mathrm{~g})}=2 \mathrm{MgF}_{2(\mathrm{~s})}+2 \mathrm{SiO}_{2(\mathrm{~s})} \\
\Delta \mathrm{G}_{\mathrm{T}}=-271.244+0.221 \mathrm{~T} \mathrm{~kJ} / \mathrm{mol} .
\end{gathered}
$$

Based on Equations (4) and (10), the initial temperatures of the two reactions were 1398 and 1312 $\mathrm{K}$, which corresponded to the two endothermic peaks in Figure 12.

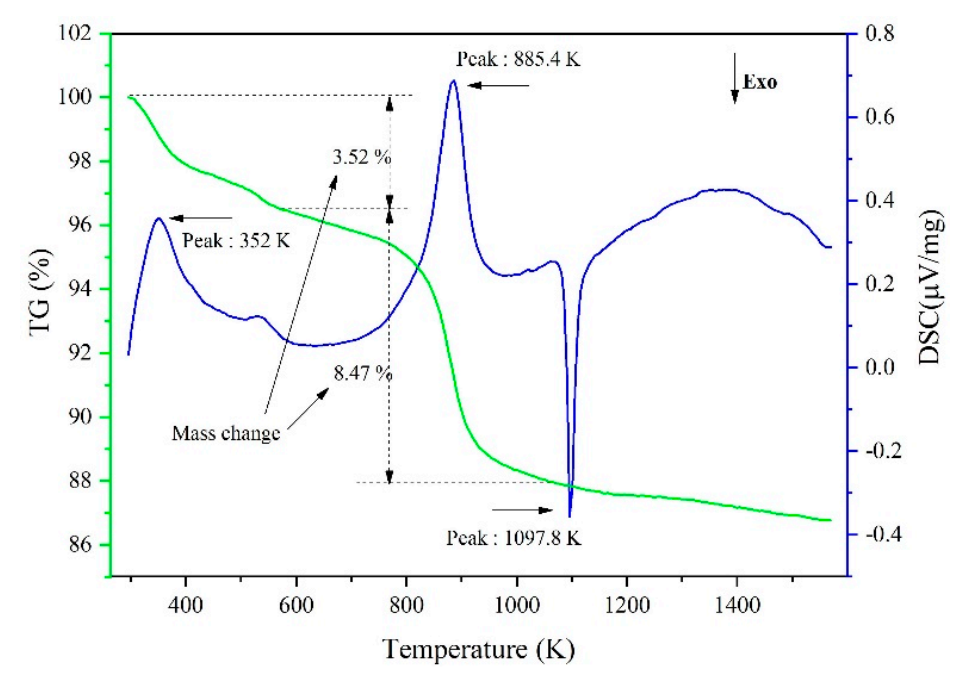

Figure 11. Thermogravimetry-differential scanning calorimetry (TG and DSC) curves of the raw materials. 


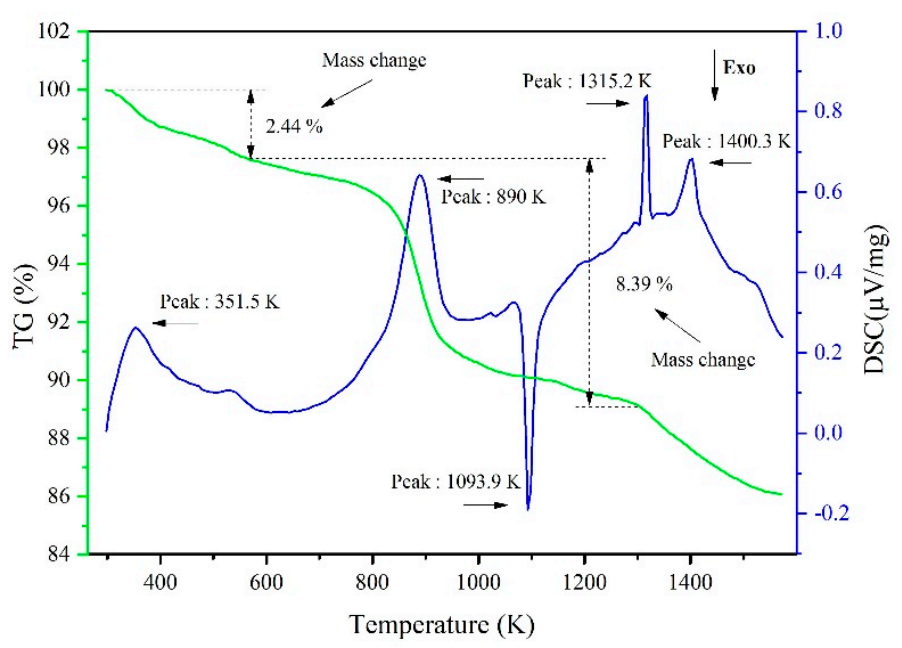

Figure 12. TG and DSC curves of the raw materials in presence of $\mathrm{CaF}_{2}$.

\subsection{Analysis of the Reduction Process}

After the vacuum carbothermal reduction, chemical analysis was performed on the Fe-Ni-rich residue. According to the calculation, we obtained the direct recovery of Fe and $\mathrm{Ni}$, which is plotted in Figures 13 and 14, respectively. The figures indicate that with the increase in $\mathrm{CaF}_{2}$, the grades and direct recovery of Fe and $\mathrm{Ni}$ first rose and then fell, with maximal grades and direct recovery achieved at $3 \% \mathrm{CaF}_{2}$. With increasing temperature, the curves in the figures divided into two parts. The addition of $\mathrm{CaF}_{2}$ at less than or equal to $3 \%$ was the first part, in which the grades and direct recovery of Fe and $\mathrm{Ni}$ first rose and then fell, with the best grades and direct recovery achieved at $1723 \mathrm{~K}$. The addition of $\mathrm{CaF}_{2}$ at more than $3 \%$ was the second part, in which the grades and direct recovery of Fe and $\mathrm{Ni}$ showed a downward trend.

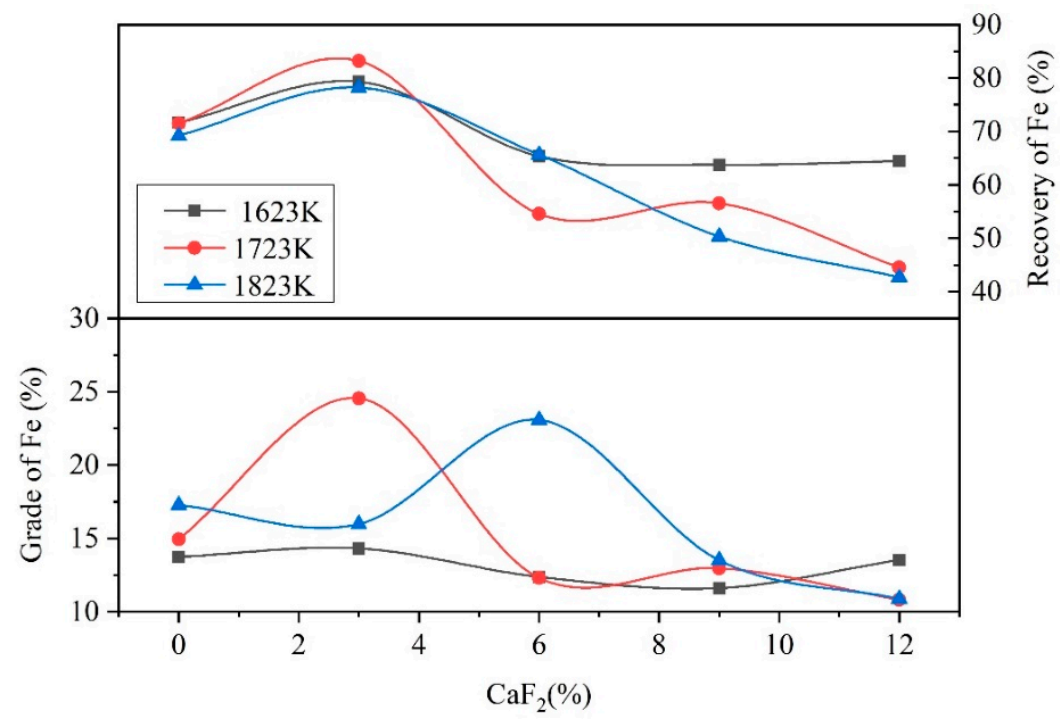

Figure 13. The effect of additives and temperature on Fe enrichment (\%), the upper three lines in the figure represents the recovery of $\mathrm{Fe}$, and the lower three lines in the figure represents the grade of Fe. 


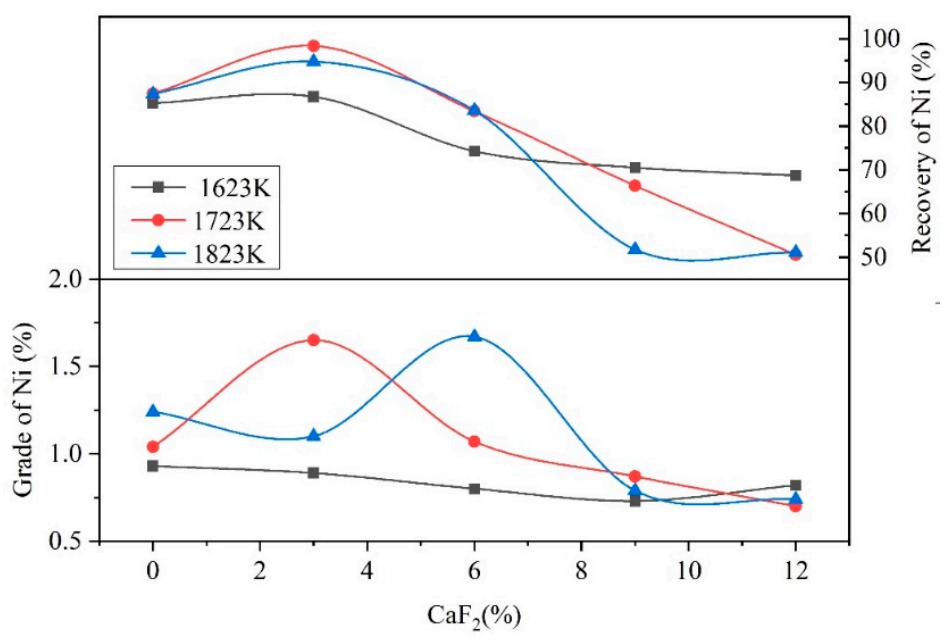

Figure 14. The effect of additives and temperature on Ni enrichment (\%), the upper three lines in the figure represents the recovery of $\mathrm{Ni}$, and the lower three lines in the figure represents the grade of $\mathrm{Ni}$.

The reasons for these results are as follows:

(1) When the addition of $\mathrm{CaF}_{2}$ was $0 \%$, low-melting-point compounds did not form in the raw materials, and the reactions struggle to occur in the solid state in the reduction process, which caused the low grades and direct recovery of Fe and $\mathrm{Ni}$.

(2) When the addition of $\mathrm{CaF}_{2}$ was $3 \%$, the $\mathrm{CaF}_{2}$ could react with the raw materials to form low-melting-point compounds, such as $\mathrm{FeF}_{2}, \mathrm{NiF}_{2}$, and $\mathrm{MgF}_{2}$. The reduction process transformed from a solid-solid reaction to a solid-liquid reaction, which accelerated the heat transfer and the mass transfer of the materials. The Fe and Ni aggregated and grew easily in the molten materials and formed small visible Fe-Ni particles on the surface of the Fe-Ni-rich residue. The raw materials were not completely melted in the reduction process due to the low addition of $\mathrm{CaF}_{2}$. Therefore, Fe and Ni were sufficiently reduced in the raw materials, which results in high grades and direct recovery of $\mathrm{Fe}$ and $\mathrm{Ni}$.

(3) When the addition of $\mathrm{CaF}_{2}$ was more than $3 \%$, a large amount of the low-melting-point compounds formed in the raw materials, which caused the raw materials to change from a solid-solid reaction to a liquid-liquid reaction. This in turn caused the reduction of Fe and $\mathrm{Ni}$ to aggregate and grow into large metal particles with diameters of $20 \mathrm{~mm}$. However, the coking coal would not melt at the experimental temperature due to its high melting point, and the density of the coking coal was low, which caused stratification of the molten materials and floating in the upper layer. This resulted in the reducing agent being unable to fully contact the raw materials, preventing the reduction process from occurring, which drastically reduced the grades and direct recovery of $\mathrm{Fe}$ and $\mathrm{Ni}$.

(4) Due to excessively high temperatures during the reduction process, the raw materials melted completely at temperature of $1823 \mathrm{~K}$ with $3 \% \mathrm{CaF}_{2}$, hindering the reduction process, which reduced the grades and the direct recovery of Fe and Ni. Therefore, the grades and direct recovery of Fe and $\mathrm{Ni}$ were lower than $1723 \mathrm{~K}$ with $3 \% \mathrm{CaF}_{2}$.

Our analyses demonstrate that the addition of $3 \% \mathrm{CaF}_{2}$ at $1723 \mathrm{~K}$ is the optimal condition.

According to Figure 15, with increasing temperature and $\mathrm{CaF}_{2}$, the grades and recovery of $\mathrm{Si}$ showed a downward trend because $\mathrm{Si}$ would volatilize in the form of $\mathrm{SiO}$ and $\mathrm{SiF}_{4}$ at high temperature, which resulted in low grades and direct recovery of Si. The equations are expressed in Equations (7)-(9) and (11)-(13). 


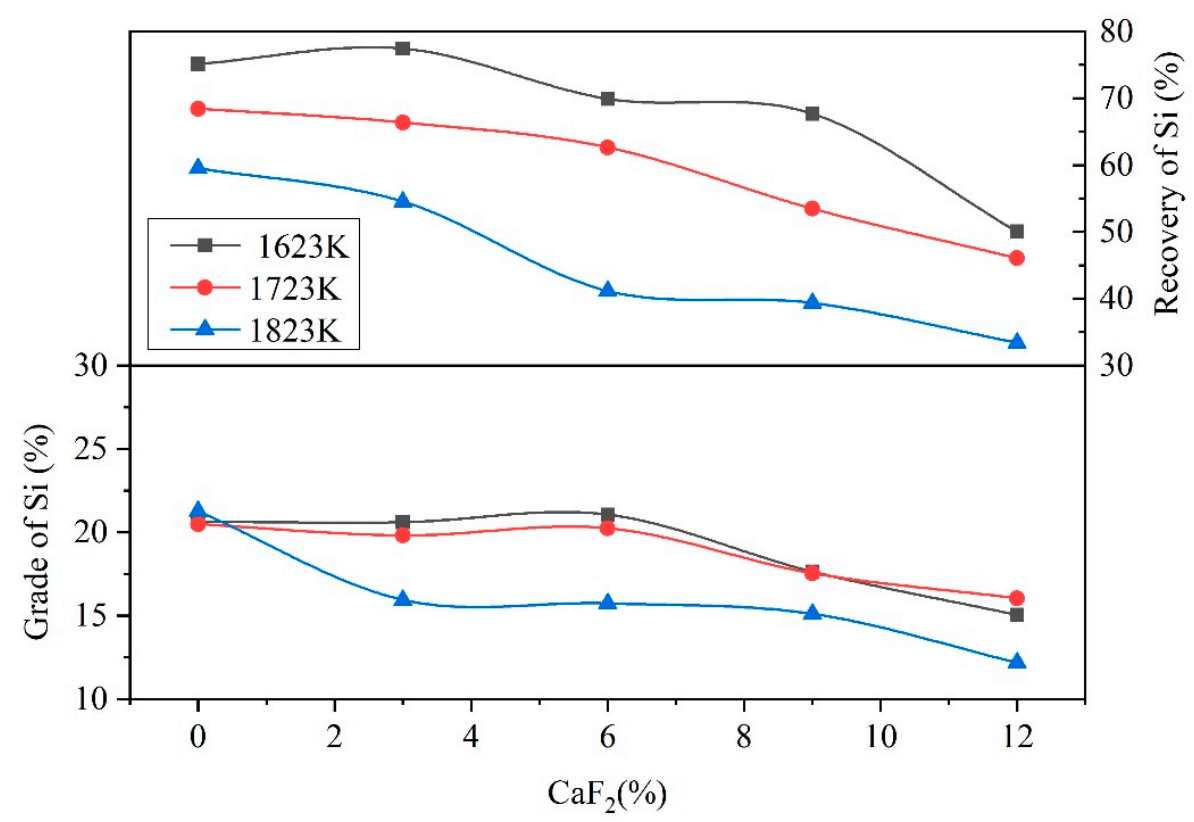

Figure 15. The effect of additives and temperature on Si enrichment (\%). The upper three lines in the figure represents the recovery of $\mathrm{Si}$, and the lower three lines in the figure represents the grade of $\mathrm{Si}$.

According to Equations (7)-(9) and (11)-(13), the initial temperatures of these reactions were $1472,808,618,1086,961$, and $1432 \mathrm{~K}$, respectively. All the reactions could occur under experimental conditions. These analysis results were consistent with the above four explanations.

Figure 16 shows that the removal rate of $\mathrm{Mg}$ increased with increasing temperature and $\mathrm{CaF}_{2}$ content. However, the removal rate was low because the raw materials changed from a solid-solid reaction to a liquid-liquid reaction with increasing $\mathrm{CaF}_{2}$ content, which caused the reduction of $\mathrm{Mg}$ to only occur in the early period. However, after the materials melted completely, the coking coal and the raw materials were stratified, which preventing the coking coal from contacting the raw materials. The steam of the $\mathrm{Mg}$ could not pass through the transition layer, resulting in the removal rate of $\mathrm{Mg}$ increasing slowly. The best example of this was at a temperature of $1823 \mathrm{~K}$ with $3 \% \mathrm{CaF}_{2}$, where the removal rate of $\mathrm{Mg}$ was significantly lower than $1723 \mathrm{~K}$ with $3 \% \mathrm{CaF}_{2}$. These analysis results were consistent with the findings in Section 3.2.

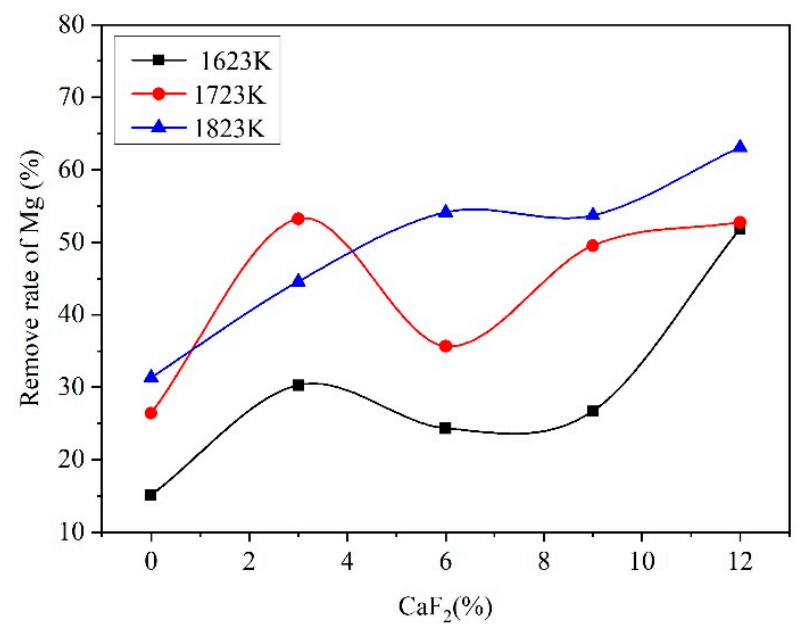

Figure 16. The effect of additives and temperature of $\mathrm{Mg}$ removal rate (\%).

As seen in Figures 13-16, we can conclude that adding 3\% $\mathrm{CaF}_{2}$ is beneficial to the recovery of $\mathrm{Ni}$ and $\mathrm{Fe}$, however, the recovery of $\mathrm{Si}$ and $\mathrm{Mg}$ are not good enough. At $1723 \mathrm{~K}$, the recovery 
of $\mathrm{Si}$ is less than $45 \%$ and the recovery of $\mathrm{Mg}$ is less than $55 \%$. The effect of temperature and the adding amount of $\mathrm{CaF}_{2}$ on the recovery of $\mathrm{Si}$ and $\mathrm{Mg}$ showed the opposite trend, that is, with the increase of temperature and the amount of $\mathrm{CaF}_{2}$, the recovery of $\mathrm{Si}$ showed a downward trend, while the recovery of $\mathrm{Mg}$ showed an upward trend. This become a contradiction point for recovering of garnierite comprehensively, therefore, the recovery of $\mathrm{Si}$ and $\mathrm{Mg}$ will not be ideal if only adding $\mathrm{CaF}_{2}$. Our previous research [29] has proved that $\mathrm{CaO}$ can greatly enhance the recovery of $\mathrm{Si}$ and $\mathrm{Mg}$. $\mathrm{We}$ could consider the mixture of $\mathrm{CaF}_{2}-\mathrm{CaO}$ as an additive to achieve the purpose of comprehensive recovery of valuable metals from garnierite.

\subsection{Phase Analysis of Fe-Ni-Rich Residue}

Figures 17 and 18 show that the main phases of the Fe-Ni-rich residue were forsterite, spinel, and $\mathrm{FeSi}$, as well as a small amount of $\mathrm{CaSiO}_{3}$ and low-melting-point compounds $\left(\mathrm{FeF}_{2}, \mathrm{NiF}_{2}\right.$, and $\mathrm{MgF}_{2}$ ). According to the literature, forsterite, $\mathrm{Fe}_{2} \mathrm{SiO}_{4}$, and $\mathrm{Ni}_{2} \mathrm{SiO}_{4}$ are mainly produced after the dehydroxylation of lizardite. Forsterite can react with coking coal to form $\mathrm{Mg}$ steam at high temperatures. However, the Fe-Ni-rich residue was mainly forsterite in this experiment, which indicated that most of the forsterite did not participate in the reduction reaction.

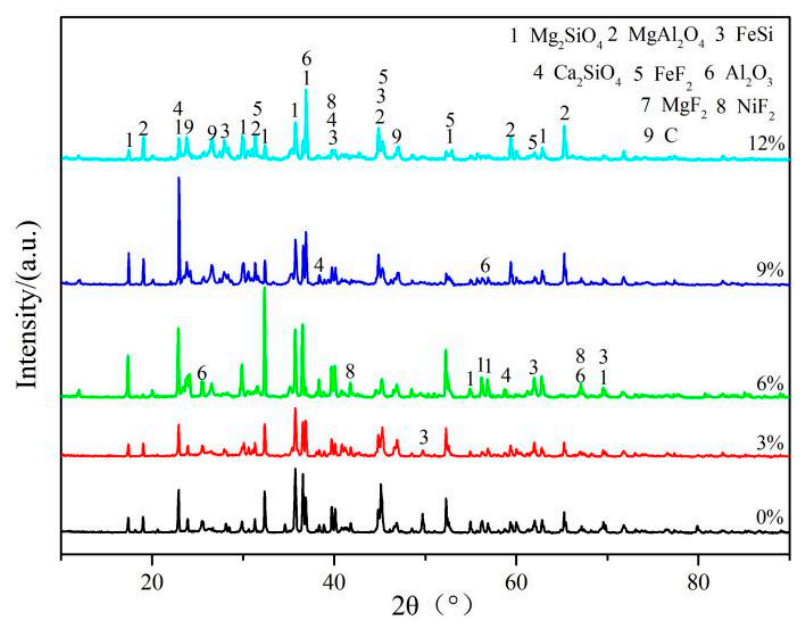

Figure 17. XRD patterns of the Fe-Ni-rich residue at $1723 \mathrm{~K}$ with $0-12 \% \mathrm{CaF}_{2}$.

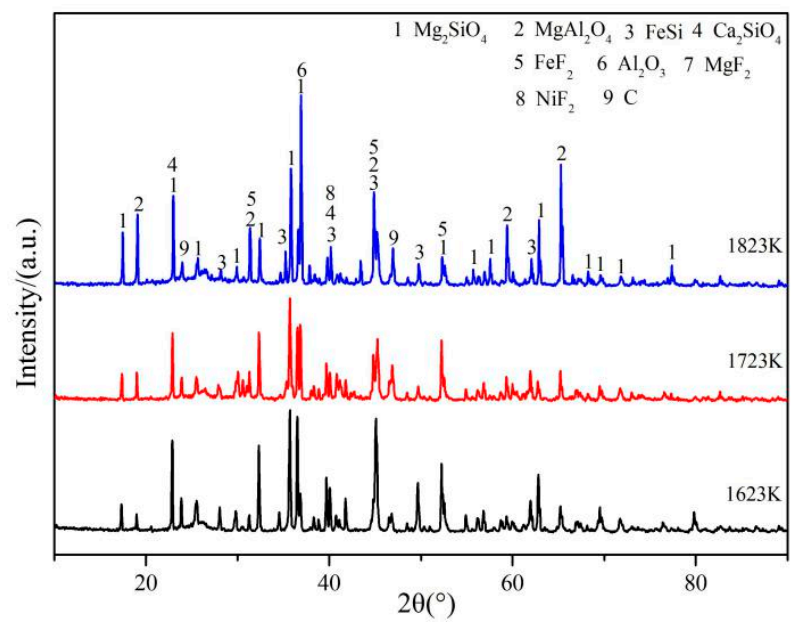

Figure 18. $\mathrm{XRD}$ patterns of the Fe-Ni-rich residue at different temperatures with $3 \% \mathrm{CaF}_{2}$.

After the lizardite decomposed, the $\mathrm{CaF}_{2}$ reacted with $\mathrm{Fe}_{2} \mathrm{SiO}_{4}$ and $\mathrm{Ni}_{2} \mathrm{SiO}_{4}$ to form low-melting-point compounds $\left(\mathrm{FeF}_{2}, \mathrm{NiF}_{2}\right.$, and $\left.\mathrm{MgF}_{2}\right)$, as shown in Figure 17. With increases in $\mathrm{CaF}_{2}$ and temperature, the raw materials changed from the solid to the liquid state. This caused some of the forsterite to react 
with the coking coal during the melting process, although a large part of forsterite could not react with coking coal due to the stratification after the raw materials melted completely, which caused a large amount of the forsterite to remain in the Fe-Ni-rich residue. The proportion of $\mathrm{Ca}$ in the raw materials was less than that of $\mathrm{Si}$, the reduction of $\mathrm{Fe}$ and $\mathrm{Ni}$ could have combined with $\mathrm{Si}$ to form $\mathrm{Si}-\mathrm{Fe}-\mathrm{Ni}$ ternary alloy particles, and the proportion of $\mathrm{Ni}$ was low. Therefore, the Si-Fe-Ni ternary alloy showed up as an Fe-Si peak in the XRD pattern. The forsterite and the $\mathrm{Al}_{2} \mathrm{O}_{3}$ could have reacted to form spinel, which caused a spinel peak to be found in the Fe-Ni-rich residue. The equations were expressed as Equations (5) and (6) in Section 3.1.

According to Equations (5) and (6), the initial temperatures of the two reactions were $875 \mathrm{~K}$ and $1691 \mathrm{~K}$. These results indicate that the reaction in Equation (5) more easily occurred than that in Equation (6), which meant the spinel could be produced under experimental conditions.

As shown in Figure 18, at $1723 \mathrm{~K}$ with $3 \% \mathrm{CaF}_{2}$, the forsterite peak was weakest and the Fe-Si peak was strongest, which indicates that the reduction of the raw materials was effective under these conditions.

\subsection{Mechanism of $\mathrm{CaF}_{2}$ in the Reduction Process}

TG-DSC and thermodynamic analysis indicated that the solid materials began to melt at $1315 \mathrm{~K}$ and $1400 \mathrm{~K}$ and produced low melting point eutectic materials $\left(\mathrm{NiF}_{2}\right.$ and $\left.\mathrm{FeF}_{2}\right)$ as heating progressed. In the reduction progress, the raw materials reacted with $\mathrm{CaF}_{2}$ to produce $\mathrm{SiF}_{4}$, and forsterite reacted with $\mathrm{SiF}_{4}$ to form another low melting point eutectic material, $\mathrm{MgF}_{2}$, which further accelerated the melting of the materials, causing the materials to transition from solid to liquid. The melting point of $\mathrm{NiF}_{2}$ is $1653 \mathrm{~K}$ at $1 \mathrm{~atm}$, the boiling point is $1772 \mathrm{~K}$, the melting point of $\mathrm{FeF}_{2}$ is $1243 \mathrm{~K}$, the boiling point is $1373 \mathrm{~K}$, and $\mathrm{FeF}_{2}$ undergoes sublimation at $1373 \mathrm{~K}$. At $50 \mathrm{~Pa}$, the melting points of $\mathrm{NiF}_{2}$ and $\mathrm{FeF}_{2}$ decrease, therefore, once $\mathrm{FeF}_{2}$ is formed, it undergoes sublimation and $\mathrm{NiF}_{2}$ volatilizes simultaneously. According to the thermodynamics calculations, the initial temperature where $\mathrm{MgF}_{2}$ forms is $1227 \mathrm{~K}$, the melting point of $\mathrm{MgF}_{2}$ is $1534 \mathrm{~K}$, and the boiling point is $2533 \mathrm{~K}$, therefore, $\mathrm{MgF}_{2}$ would not have volatilized under the experimental conditions.

The 20-mm-diameter Fe-Ni-Si ternary alloy collected in the experiment showed that the melted materials accelerated the heat transfer and the mass transfer of Fe and Ni, promoting the FeNi particles to aggregate and grow. With increasing temperature and the increase in addition of $\mathrm{CaF}_{2}$, the volatility of $\mathrm{Si}$ in the form of $\mathrm{SiO}$ and $\mathrm{SiF}_{4}$ were promoted, causing a sharp drop in the recovery of $\mathrm{Si}$. Due to the density of coking coal being less than that of $\mathrm{MgAl}_{2} \mathrm{O}_{4}, \mathrm{MgAl}_{2} \mathrm{O}_{4}$ being less dense than $\mathrm{Mg}_{2} \mathrm{SiO}_{4}$, and $\mathrm{Mg}_{2} \mathrm{SiO}_{4}$ being less dense than $\mathrm{Fe}-\mathrm{Ni}-\mathrm{Si}$ ternary alloy, the materials stratified. The stratification of the raw materials and coking coal hindered the reduction of $\mathrm{Mg}$, causing a slow increase in the removal rate of $\mathrm{Mg}$, as shown in Figure 19.

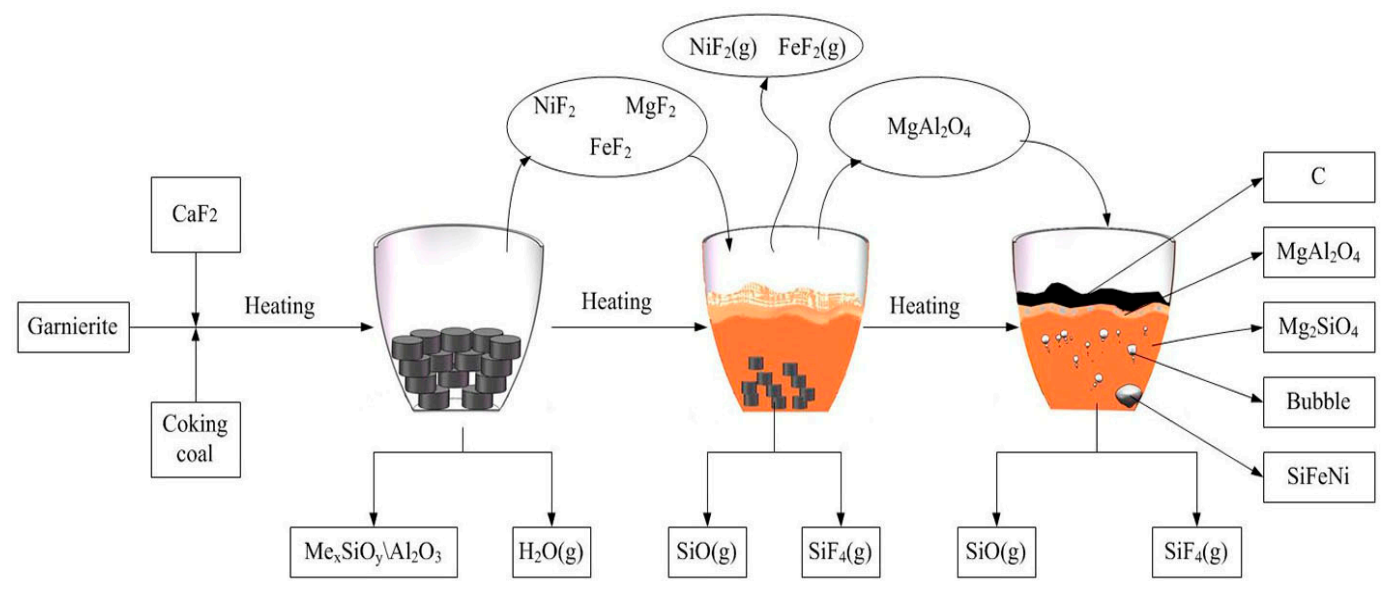

Figure 19. The influence and behavior of $\mathrm{CaF}_{2}$ on the reduction process. 


\subsection{Magnetic Separation Process}

Table 4 shows that after the magnetic separation, the grades of Fe were low, probably because Fe was present in the forsterite and spinel during the reduction process, which resulted in a low chemical analysis result. At the optimal conditions, the direct recoveries of Fe and Ni were 82.97\% and 98.21\%, respectively, in the vacuum carbothermal reduction-magnetic separation process, and the enrichment ratios were 3.18 and 9.35, respectively, as shown in Table 5. The data in the tables indicate that adding a proper amount of $\mathrm{CaF}_{2}$ could effectively improve the grades and recovery of $\mathrm{Fe}$ and $\mathrm{Ni}$.

Table 4. The content and recovery of Fe and Ni using the magnetic separation process and using the vacuum carbothermal reduction-magnetic separation process.

\begin{tabular}{|c|c|c|c|c|c|c|c|}
\hline \multirow[t]{2}{*}{$\begin{array}{l}\text { Temperature } \\
\text { (K) }\end{array}$} & \multirow[t]{2}{*}{$\begin{array}{c}\mathrm{CaF}_{2} \\
\text { (wt. \%) }\end{array}$} & \multirow{2}{*}{$\begin{array}{l}\text { Quality of } \\
\text { Magnetic } \\
\text { Material (g) }\end{array}$} & \multicolumn{2}{|c|}{$\begin{array}{l}\text { Chemical Analysis of } \\
\text { Fe, Ni in Magnetic } \\
\text { Materials (\%) }\end{array}$} & \multirow{2}{*}{$\begin{array}{c}\text { Quality of } \\
\text { Non-Magnetic } \\
\text { Material (g) }\end{array}$} & \multicolumn{2}{|c|}{$\begin{array}{l}\text { Chemical Analysis of } \\
\text { Fe, Ni in Non-Magnetic } \\
\text { Materials (\%) }\end{array}$} \\
\hline & & & $\mathrm{Fe}$ & $\mathrm{Ni}$ & & $\mathrm{Fe}$ & $\mathrm{Ni}$ \\
\hline 1623 & 3 & 24.49 & 32.46 & 5.18 & 35.66 & 0.42 & 0.04 \\
\hline 1823 & 3 & 30.29 & 38.17 & 5.99 & 21.71 & 0.33 & 0.05 \\
\hline 1723 & 0 & 50.54 & 14.95 & 1.04 & 50.54 & 0.00 & 0.00 \\
\hline 1723 & 3 & 11.16 & 40.20 & 6.73 & 21.75 & 0.18 & 0.03 \\
\hline 1723 & 6 & 23.61 & 38.30 & 6.69 & 50.57 & 0.23 & 0.07 \\
\hline 1723 & 9 & 23.06 & 37.30 & 6.22 & 49.73 & 0.26 & 0.06 \\
\hline 1723 & 12 & 19.03 & 34.75 & 5.11 & 49.13 & 0.38 & 0.02 \\
\hline
\end{tabular}

Table 5. Enrichment ratio of $\mathrm{Fe}$ and $\mathrm{Ni}$ with different dosages of $\mathrm{CaF}_{2}$ at different temperature and Recovery of Fe and Ni during the vacuum carbothermal reduction-magnetic separation process.

\begin{tabular}{cccccccc}
\hline Temperature (K) & $\mathbf{1 6 2 3}$ & $\mathbf{1 8 2 3}$ & $\mathbf{1 7 2 3}$ & $\mathbf{1 7 2 3}$ & $\mathbf{1 7 2 3}$ & $\mathbf{1 7 2 3}$ & $\mathbf{1 7 2 3}$ \\
\hline $\mathrm{CaF}_{2}($ wt $\%)$ & 3 & 3 & 0 & 3 & 6 & 9 & 12 \\
Enrichment ratio of Fe (\%) & 2.56 & 3.02 & 1.18 & 3.18 & 3.03 & 2.95 & 2.75 \\
Enrichment ratio of Ni (\%) & 7.19 & 8.32 & 1.44 & 9.35 & 9.29 & 8.64 & 7.10 \\
Recovery of Fe (\%) & 73.19 & 73.87 & 71.50 & 82.97 & 54.03 & 51.55 & 40.90 \\
Recovery of Ni (\%) & 84.89 & 93.62 & 87.45 & 98.21 & 81.19 & 64.64 & 48.69 \\
\hline
\end{tabular}

\section{Conclusions}

A vacuum carbothermal reduction-magnetic separation method to recover $\mathrm{Ni}$, $\mathrm{Fe}$, and $\mathrm{Mg}$ from garnierite was proposed, and the experiments indicated that the optimal conditions for this method for the recovery of $\mathrm{Fe}$ and $\mathrm{Ni}$ are $1723 \mathrm{~K}$, a molar ratio of ore/C of 1:1.2, and the addition of $\mathrm{CaF}_{2}$ at $3 \%$. The recovery of Fe and Ni reached $82.97 \%$ and $98.21 \%$, respectively, in the vacuum carbothermal reduction-magnetic separation process, and the enrichment ratios of Fe and Ni reached a maximum of 3.18 and 9.35 , respectively.

The $\mathrm{CaF}_{2}$ in the vacuum carbothermal process formed low-melting-point compounds $\left(\mathrm{FeF}_{2}\right.$ and $\mathrm{NiF}_{2}$ ) at $1315 \mathrm{~K}$ and $1400 \mathrm{~K}$, respectively, to transform the raw materials from solid to liquid, which accelerated the mass transfer and the heat transfer of Fe-Ni particles, and formed $\mathrm{Si}-\mathrm{Ni}-\mathrm{Fe}$ alloy particles with diameters of approximately of $20 \mathrm{~mm}$. Simultaneously, the smelting materials appeared stratified, hindering the reduction of magnesium.

The removal rate of $\mathrm{Mg}$ increased and the maximal recovery only reached $74.12 \%$. The reason for this low $\mathrm{Mg}$ removal rate is the stratification of the coking coal and the molten materials, which limited the increase in the recovery of $\mathrm{Mg}$. However, the recovery of $\mathrm{Si}$ and the removal rate of $\mathrm{Mg}$ showed the opposite trend, this becomes a contradiction point for recovering garnierite comprehensively. Previously, we used this method to recover $\mathrm{Ni}, \mathrm{Fe}, \mathrm{Si}$, and $\mathrm{Mg}$ with $\mathrm{CaO}$ as an additive, achieved some good experiment results, especially for the removal rate of $\mathrm{Mg}$ [29]. Subsequently, we could consider the mixture of $\mathrm{CaF}_{2}-\mathrm{CaO}$ as an additive to solve the contradiction of $\mathrm{Si}$ and $\mathrm{Mg}$, and achieve the purpose of comprehensive recovery of valuable metals from garnierite. 
The method used in this article can solve the problem of the large amounts of slag produced and the inability to recycle the magnesium in the traditional pyrometallurgical process. For the future industrial application, it is necessary to solve the problem of magnesium condensation technology. If magnesium can be recycled in a reduction process, not only can it increase the economic benefits of enterprises, but it can also solve the problem of environment pollution, therefore, it has a certain industrialization significance. In addition, this article clarifies the behavior mechanism of $\mathrm{CaF}_{2}$ in the reduction process of garnierite, it can be used for reference in guiding industrial production.

Author Contributions: Conceptualization, T.Q.; writing—original draft preparation, Q.W.; writing-review and editing, X.G., M.L. and L.S.; funding acquisition, B.Y. and Y.D. All authors have read and agree to the published version of the manuscript.

Funding: This work was funded by the National Nature Science Foundation of China (No. 51604133) and the Academician Free Exploration Fund of Yunnan Province, China (No. 2019HA006).

Conflicts of Interest: The authors declare no conflict of interest.

\section{References}

1. Esmaeili, N.; Ojo, O.A. Analysis of Brazing Effect on Hot Corrosion Behavior of a Nickel-Based Aerospace Superalloy. Metall. Mater. Trans. B 2018, 49, 912-918. [CrossRef]

2. Zhang, L.N.; Szpunar, J.A.; Dong, J.X.; Ojo, O.A.; Wang, X. Dependence of Crystallographic Orientation on Pitting Corrosion Behavior of Ni-Fe-Cr Alloy 028. Metall. Mater. Trans. B 2018, 49, 919-925. [CrossRef]

3. Saad, E.A.; Hassanien, M.M.; Ellban, F.W. Nickel(II) diacetyl monoxime-2-pyridyl hydrazone complex can inhibit Ehrlich solid tumor growth in mice: A potential new antitumor drug. Biochem. Biophys. Res. Commun. 2017, 484, 579-585. [CrossRef] [PubMed]

4. Nasab, M.B.; Hassan, M.R. Metallic Biomaterials of Knee and Hip-A Review. Trends Biomater. Artif. Organs 2010, 24, 69-82.

5. Babić, M.M.; Božić, B.Đ.; Božić, B.Đ.; Filipović, J.M.; Ušćumlić, G.S.; Tomić, S.L. Evaluation of novel antiproliferative controlled drug delivery system based on poly(2-hydroxypropyl acrylate/itaconic acid) hydrogels and nickel complex with Oxaprozin. Mater. Lett. 2016, 163, 214-217. [CrossRef]

6. Setcos, J.C.; Mahani, A.B.; Silvio, L.D.; Mjor, I.A.; Wilson, N.H.F. The safety of nickel containing dental alloys. Dent. Mater. 2006, 22, 1163-1168. [CrossRef] [PubMed]

7. Zhang, L.; Yang, H.P.; Cao, F.; Feng, A.S.; Zhao, J.W. Study on Current Situation and Analysis of Supply and Demand of Global Nickel Resource. Conser. Utilizat. Miner. Resour. 2016, 1, 64-69.

8. Zong, K.; Zhou, J.Y.; Fu, S.X. Study on global market allocation of Chinese nickel metal resources. Miner. Explor. 2015, 6, 86-91.

9. Valix, M.; Tang, J.Y.; Cheung, W.H. The effects of mineralogy on the biological leaching of nickel laterite ores. Miner. Eng. 2001, 14, 1629-1635. [CrossRef]

10. Myagkiy, A.; Truche, L.; Cathelineau, M.; Golfier, F. Revealing the conditions of Ni mineralization in the laterite profiles of New Caledonia: Insights from reactive geochemical transport modelling. Chem. Geol. 2017, 466, 274-284. [CrossRef]

11. Alfantazi, A.M.; Moskalyk, R.R. Nickel laterite processing and electrowinning practice. Miner. Eng. 2002, 15, 593-605.

12. Ma, B.Z.; Wang, C.Y.; Yang, W.J.; Chen, Y.Q.; Yang, B. Comprehensive utilization of Philippine laterite ore, part 1: Design of technical route and classification of the initial ore based on mineralogical analysis. Int. J. Miner. Process. 2013, 124, 42-49. [CrossRef]

13. Khoo, J.Z.; Haque, N.; Bhattacharya, S. Process simulation and exergy analysis of two nickel laterite processing technologies. Int. J. Miner. Process. 2017, 161, 83-93. [CrossRef]

14. Elliott, R.; Pickles, C.A.; Forster, J. Thermodynamics of the Reduction Roasting of Nickeliferous Laterite Ores. J. Miner. Mater. Charact. Eng. 2016, 4, 320-346. [CrossRef]

15. Kursunoglu, S.; Ichlas, Z.T.; Kaya, M. Solvent extraction process for the recovery of nickel and cobalt from Caldag laterite leach solution: The first bench scale study. Hydrometallurgy 2017, 169, 135-141. [CrossRef] 
16. Leonardou, S.A.; Tsakiridis, P.E.; Oustadakis, P.; Karidakis, T.; Katsiapi, A. Hydrometallurgical process for the separation and recovery of nickel from sulphate heap leach liquor of nickeliferrous laterite ores. Miner. Eng. 2009, 22, 1181-1192. [CrossRef]

17. Ma, B.Z.; Wang, C.Y.; Yang, W.J.; Yang, B.; Zhang, Y.L. Selective pressure leaching of Fe (II)-rich limonitic laterite ores from Indonesia using nitric acid. Miner. Eng. 2013, 45, 151-158. [CrossRef]

18. Kaya, S.; Topkaya, Y.A. High pressure acid leaching of a refractory lateritic nickel ore. Miner. Eng. 2011, 24, 1188-1197. [CrossRef]

19. Johnson, J.A.; Cashmore, B.C.; Hockridge, R.J. Optimisation of nickel extraction from laterite ores by high pressure acid leaching with addition of sodium sulphate. Miner. Eng. 2005, 18, 1297-1303. [CrossRef]

20. Muir, B.I.; Whittington, D. Pressure acid leaching of nickel laterites: A review. Miner. Process. Extr. Metall. Rev. 2000, 21, 527-599.

21. Dodbiba, G.; Kim, J.; Tanno, H.; Okaya, K.; Matsuo, S.; Fujita, T. Calcination of low-grade laterite for concentration of Ni by magnetic separation. Miner. Eng. 2010, 23, 282-288.

22. Li, G.H.; Shi, T.M.; Rao, M.J.; Zhang, Y.B. Beneficiation of nickeliferous laterite by reduction roasting in the presence of sodium sulfate. Miner. Eng. 2012, 32, 19-26. [CrossRef]

23. Zhu, D.Q.; Cui, Y.; Vining, K.; Hapugoda, S.; Douglas, J.; Pan, J.; Zheng, G.L. Upgrading low nickel content laterite ores using selective reduction followed by magnetic separation. Int. J. Miner. Process. 2012, 106-109, 1-7. [CrossRef]

24. Ma, B.Z.; Xing, P.; Yang, W.J.; Wang, C.Y.; Chen, Y.Q.; Wang, H. Solid-State Metalized Reduction of Magnesium-Rich Low-Nickel Oxide Ores Using Coal as the Reductant Based on Thermodynamic Analysis. Metall. Mater. Trans. B 2017, 48, 2037-2046. [CrossRef]

25. Cao, C.; Xue, Z.L.; Duan, H.J. Making Ferronickel from Laterite Nickel Ore by Coal-Based Self-Reduction and High Temperature Melting Process. Int. J. Nonfer. Metall. 2016, 5, 9-15. [CrossRef]

26. Li, J.H.; Chen, Z.F.; Shen, B.P.; Xu, Z.F.; Zhang, Y.F. The extraction of valuable metals and phase transformation and formation mechanism in roasting-water leaching process of laterite with ammonium sulfate. J. Clean. Prod. 2017, 140, 1148-1155. [CrossRef]

27. Xu, C.; Cheng, H.W.; Li, G.S.; Lu, C.Y.; Lu, X.G.; Zou, X.L.; Xu, Q. Extraction of metals from complex sulfide nickel concentrates by low-temperature chlorination roasting and water leaching. Int. J. Miner. Metall. 2017, 24, 377-385. [CrossRef]

28. Zhou, S.W.; Wei, Y.G.; Li, B.; Ma, B.Z.; Wang, C.Y.; Wang, H. Kinetics study on the dehydroxylation and phase transformation of $\mathrm{Mg}_{3} \mathrm{Si}_{2} \mathrm{O}_{5}(\mathrm{OH})_{4}$. J. Alloys Compd. 2017, 713, 180-186. [CrossRef]

29. Wang, Q.; Qu, T.; Gu, X.P.; Shi, L.; Yang, B.; Dai, Y.N. The effect of CaO on the recovery of Fe and Ni in a vacuum carbothermal reduction of garnierite. J. Min. Metall. Sect. B Metall. 2019, 55, 351-358. [CrossRef] 